\title{
Locational Analysis of Police Stations In Bauchi Metropolis Using GIS Systems
}

\author{
${ }^{1}$ Ikharo I. Blessing, ${ }^{2}$ Ikharo A. Braimoh
}

${ }^{1}$ Department of Surveying and Geoinformatics, Nnamdi Azikiwe University, Awka Anambra State, Nigeria ${ }^{2}$ Department of Computer Engineering, Edo University Iyamho, Iyamho, Edo State, Nigeria

\begin{abstract}
Given the security problem in Nigeria particularly in the North, the need for geospatial analysis of security in Bauchi metropolis in relation to police stations cannot be overemphasized. Apart from the prevalence of security problem in the area current analyses are inadequate, almost non-existent. To tackle this problem, Global Positioning System (GPS) was used to take the coordinates of the police stations in the study area, while the attribute data relating to the number of police personnel in each station were collected using interview and documented data. The data were analysed using simple ratio. Also ArcGIS (Version 10.0) software was used to show the map of the distribution. A nearest neighbourhood analysis has shown that the distribution of stations is random in the area. One and two kilometre buffer zones were generated and the result shows that the old city of Bauchi and the eastern part of the metropolis were fully served while the western and southern parts were underserved. The ratio of population in the area to a police is $898: 1$ which is far below the United Nation recommended figure of 450:1. The work recommends that there is need for population consideration in citing police stations in the area as well as increasing the work force as means for achieving a holistic security for the metropolis.
\end{abstract}

Keywords : Metropolis, Buffer Zones, Police Station, Bauchi, GIS, Security, Population.

\section{INTRODUCTION}

For the past decade, Bauchi metropolis has had influx of people that have put the town's infrastructure under stress. With this growing population, an increasing demand for land use, water supply, security, high cost of living and high traffic of vehicular and human movement are experienced. This in itself has contributed to the concentration and congestion of urban dwellers in the metropolis thereby creating hot spots for possible miscreants and vagabonds among the populace. [2] had projected that by 2007 people will be living in cities and towns than rural areas and by 2017 the developing world is likely to have become more urban in character than rural. Identifying or evaluating locations on the basis of technical, economic, social, environmental, and political criteria, possibly with conflicting objectives [10] and providing security to these locations requires complex knowledge management. This is the experience of Bauchi metropolis.

It is well recognized all over the world that peace and security of life and property are the primary conditions for progress and development of any society [5]. In every society, developed or developing, insecurity has become a way of life as some have taken to it as means of livelihood. Therefore, the need to provide security becomes indispensable for the peace and progress of the people, the community and the nation at large. This can be achieved through the instrumentality of the police force. [3] defines policing as the measures and actions taken by a variety of institutions and groups (both formal and 
non-formal) in the society to regulate social relations and practice in order to secure the safety of members of community as well as conformity to the norms and values of society. This form of control process is necessary in Bauchi metropolis for adequate surveillance of her territory and populace. This control must be equipped with tools to sanction any erring one. At present, using GIS and satellite Remote Sensing (RS) technology to monitor land use dynamics should be the main task of Law Enforcement Inspection of Satellite Land Image [12].

GIS has played a major role in identifying that framework by delineating the boundaries of community and making them practical, useful units of geographic space. This creates a sense of belonging to an area, which can serve as a mechanism to rally other communities together, draw attention to their issues, and highlight what the locality has to offer, or represent the area as a collective in a political arena [11]. Even with the advantage of modern GIS technologies, community boundaries are difficult to define. Difficulties arise because of the scale and complexity of the interlocking edges within the community and the lack of data to represent locations that are within these boundaries. Thus, a range of boundaries may define the same community, varying because of the factors and data used to create each community map.

Claims of successful use of GIS in policing have been reported in a number of cities and countries of the world. Compstat was credited with significant reduction of crime and improvement in neighborhood quality of life in New York City [8] and [9]. As means to prevent murders and aggravated succession of firearms, the Chicago Police Department's (CPD) Deployment Operations Centre deployed GIS technologies to present crime information in geographic context. The first six months of GIS deployment, the CPD saw an 18 percent drop in murders compared with the same period the year before [4]. In addition, several regional centres in America have been created to facilitate the application of geospatial crime analysis, such as the Baltimore County Police Department's Regional Crime Analysis GIS (RCAGIS) and San Diego's Automated Regional Justice Information System (ARJIS) (David and Alex, 1999). This innovation is yet to be adopted in Nigeria though efforts are on to equip states with GIS offices nationwide. Potential uses for the technology are limited only by the imaginations of individuals in the field. [6] explained that there is a general belief that the Nigerian Police has been with a strength of personnel that is far below the capacity required to police the estimated Nigerian population of approximately 120 million, considering the minimum United Nations standard. [7] used spatial and attribute data acquisition for their work on a GIS approach to crime mapping and management in Nigeria using Victoria Island of Lagos as their study location. Their work failed to address actual documented crime scene owing to its assumed number of crime incidences to areas with more crime tendencies. [1] examined the spatial distribution of police stations in Kano metropolis. They used GPS to measure the coordinates of the stations in the area while the data pertaining to the number of police personnel in each station were sources from interview and documented data source. This work failed to vividly show how the inferential statistic (chi square test) arrived at the no significant relationship between police station and population distribution as inferred.

Thus, the focus of this work is to identify by using GIS spatial analysis and attributes as well as buffer analysis to determine area coverage, putting population, area extent and land use, personnel and distribution of police stations within the Bauchi metropolis into consideration. Also, to acquire the base map of Bauchi State showing boundary locations 
and digitizing the street guide map of Bauchi Metropolis showing the road networks. A geospatial analysis of security in Bauchi metropolis in relation to police stations is timely, not only because of the prevalence of the problem but because current analyses are inadequate, almost non-existence characteristically. The challenge is to create a digital map and database containing all the police stations, police posts in Bauchi metropolis and find their proximity and spatial relationship with other points such as markets, school, medical centres, banks, religious centres and hotels.

The justification for this work stems from that fact that the current locations of the police stations do not ensure effective coverage of the areas under their jurisdictions. It is either the stations are clustered at one point, or sparsely distributed in others. The need therefore, for police officers to make sound decisions

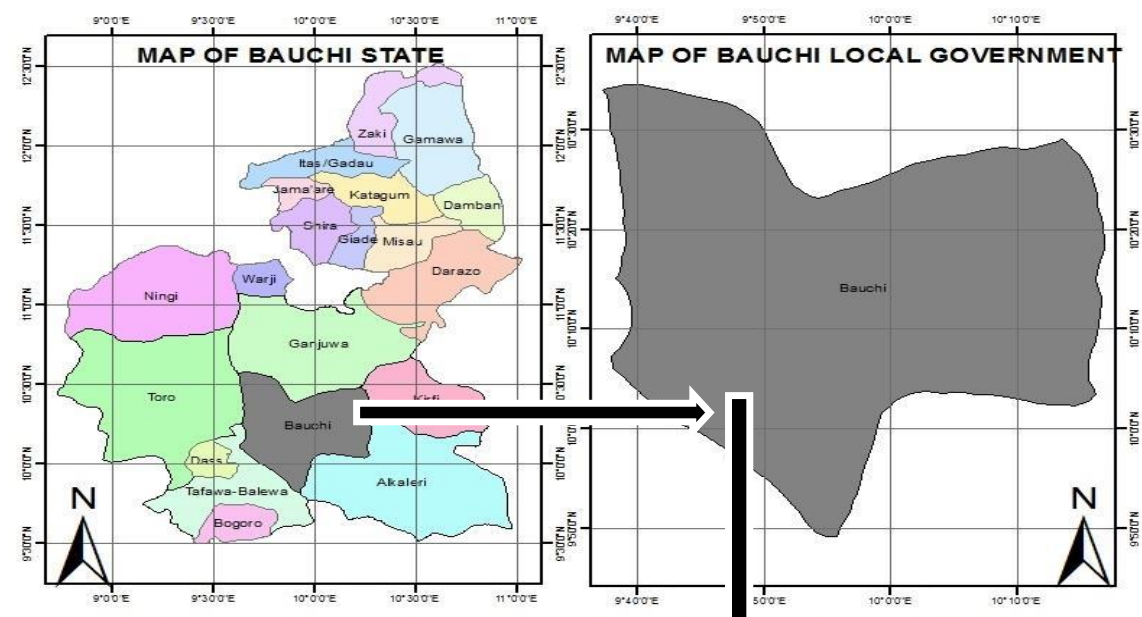

MAP OF BAUCHI METROPOLIS SHC VING STUDY AREA

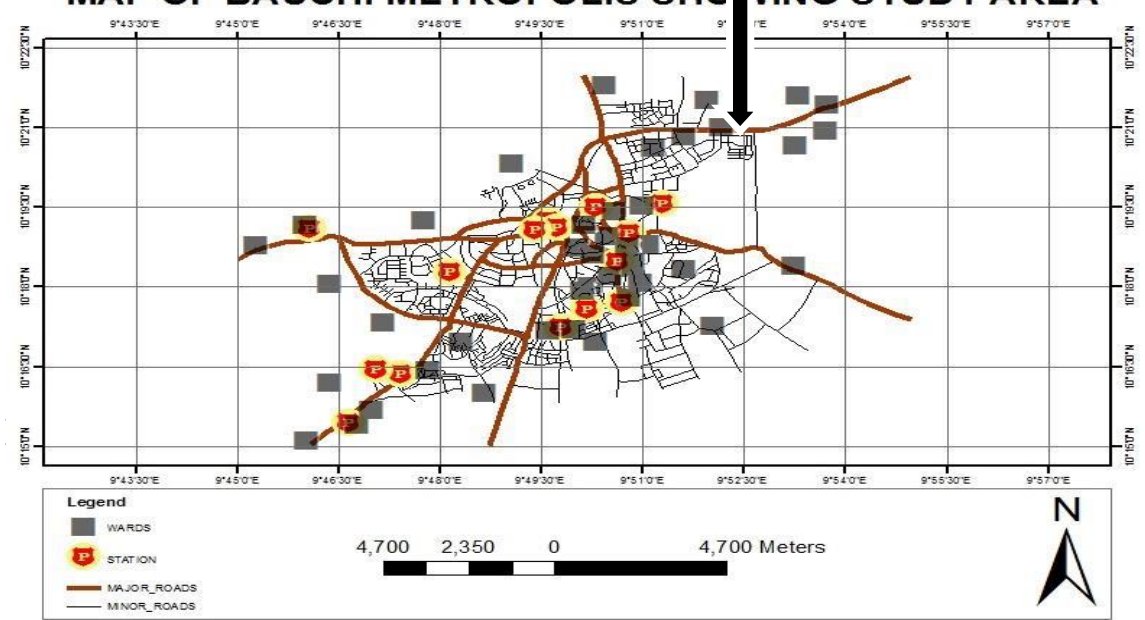

and take swift actions cannot be over emphasized and this decisions, which are mostly spatially related can be aided by a knowledge of network analysis using GIS. This is the motivating factor for this work.

\section{STUDY AREA}

Bauchi State is an administrative division of Nigeria, located in the North-Eastern part of the country. It forms one of the states making up the Federal Republic of Nigeria. Bauchi State is located between latitudes $9^{0} 3^{1} \mathrm{~N}$ and $12^{0} 3^{1} \mathrm{~N}$ of the Equator and longitude $8^{0} 50^{1} \mathrm{E}$ and $11^{\circ} \mathrm{E}$ of the Greenwich Meridian (see figure 1). The state is bordered by seven states: Kano and Jigawa to the north, Taraba and Plateau to the South, Gombe and Yobe to the east and Kaduna to the West. Bauchi State occupies a total land area of $49,359 \mathrm{~km}^{2}$ representing about $5.3 \%$ of Nigeria's total land mass.
Figure 1 : Map showing Bauchi State, LGA and Study Area Source: Bauchi State Ministry of Lands and Housing 


\section{METHODS AND MATERIAL}

\section{Data Capture}

The primary data were collected by oral interview with police officers, through carefully selected questions. Also, global positioning system (GPS) was used to collect the co-ordinates of each of the (15) police stations in the study area. The co-ordinates of the police state headquarter and the metropolitan offices were also collected. The secondary data were collected from the police headquarters in Bauchi, from where the names and addresses of all the 15 police stations (divisions) together with their strength where collected. Demographic data of the population of the area were collected from the National Population Commission (NPC), Bauchi.

\section{Base Map and Data Model}

The street guide map of Bauchi metropolis was obtained. Geocalc was used to convert the local coordinate system to UTM System, and then georeferenced. The database also included the names of the station, the roads and the street name. But not all the streets had labels, most especially those on the outskirts of Bauchi. Vector data model was adopted for this research. Vector data model is a representation of an object-based model as a collection of nodes areas and polygon.

Using Georeferencing in ArcMap simply implies the registration of coordinates in the map to be digitized. Digitizing is the act of tracing features in an already existing map for the purpose of putting or converting them to a vector format. The digitizing method used in this work is the onscreen method of digitizing using ArcMap 10.0.

\section{RESULTS AND DISCUSSION}

The final result is a digit map of Bauchi metropolis. This is presented in print form (i.e paper map) for public usage and in the original digital format for experts and GIS analyst; this digital copy is subject to query and further improvement. The attribute table obtained is a general attribute table containing locations, name, and features present in the layer. It must be noted here that all these capabilities enumerated above are for those who can have access to the digital map still in the digital environment or GIS environment.

\section{Police Stations and Personnel Distribution}

The total number of police stations in the area is fifteen (15) as shown in table 1. The stations are not even distributed, also the number of personnel.

Table 1: Number of Police Stations and Personnel

\begin{tabular}{|c|c|c|c|}
\hline OID & Station & Count_Station & Sum_Personnels \\
\hline 0 & Division & 5 & 446 \\
\hline 1 & Headquaters & 1 & 870 \\
\hline 2 & Outpost & 7 & 22 \\
\hline 3 & School & 1 & 82 \\
\hline 4 & Zone & 1 & 527 \\
\hline
\end{tabular}

The Headquarters has the highest number of police personnel, this may be attributed to the fact that it is the headquarters with different departments; example is the Criminal Investigation Department (CID).

The result of the spatial distribution of police stations in Bauchi metropolis shows an uneven distribution of police stations in the metropolis (see figure 2) the map which shows this distribution also revealed that the concentration of the police 
stations is within the central part of the area. The concentration of the police stations within the central area cannot be explained by the Christellars central place theory, which explains that, the location of services is based on seize of community, population, accessibility and proximity, putting into consideration, threshold and range.

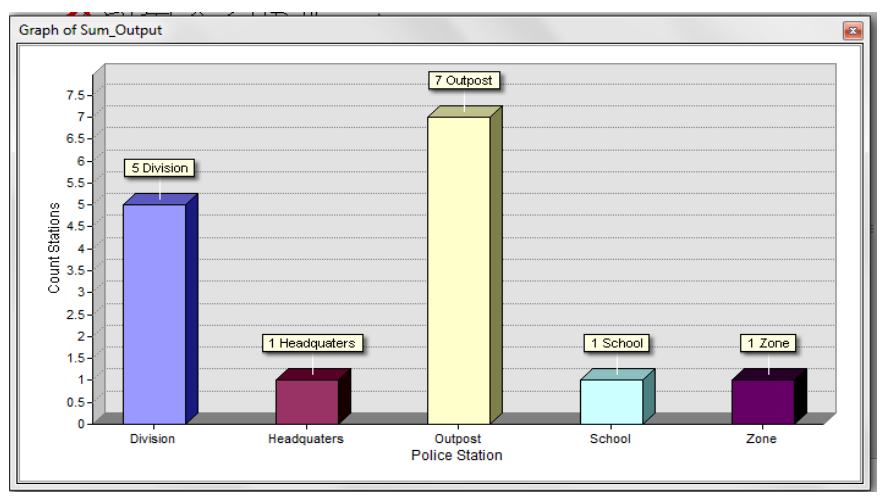

Figure 2 : Distribution of Police Station in Bauchi Metropolis

To ascertain this unevenness spread of the distribution, nearest neighbourhood analysis was used. The result shows that the pattern of the distribution is random. In other words, the police stations are not distributed evenly.

\section{Distribution of Manpower}

Like the number of police stations, man power is not evenly distributed in the area. Nearly half of the personnel (47\%) are found in the headquarters, while the remaining half is shared by the other police stations (see figure 3 ).

Comparison was made between the personnel and the different police stations that is the Divisions, Headquarters, Outpost, School, and Zone. The police personnel are categorized into three ranks. The senior officers include the Assistant Superintendent and the rank above; the inspectors and junior officer (below inspector ranks)

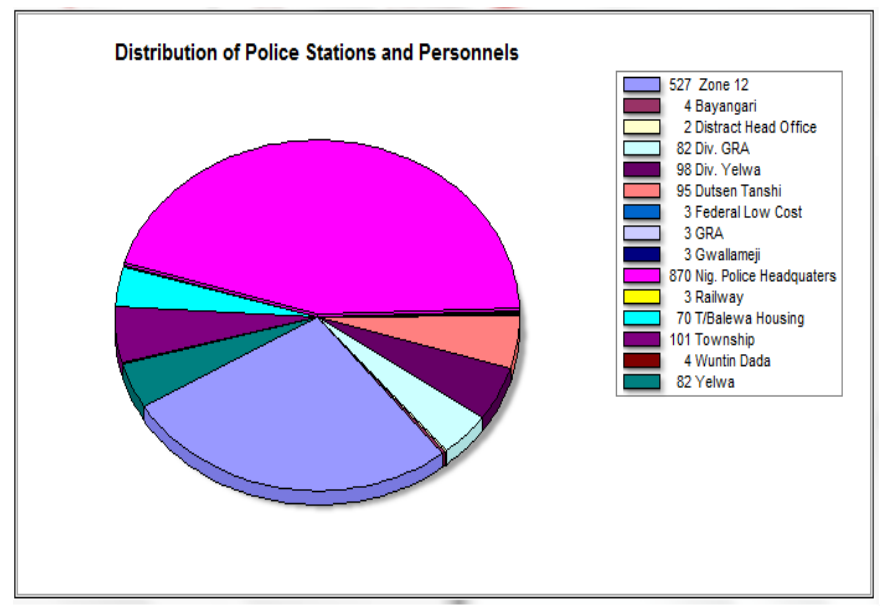

Figure 3 : Police Manpower Distribution

The research findings revealed that in all station there are more junior officers than inspectors and senior officer.

\section{Ratio of Police Men to Population}

A simple ratio was used to find the relationship between police (personnel) distribution and population distribution as shown in table 2. By the United Nations standard the ratio of population to one police is $450: 1$. Using this ratio the value in table 2 is obtained. By this result it shows that the required security is lacking for Bauchi populace is lacking implying that the police work force is inadequate.

Table 2 : Ratio of Police Personnel to Population in Bauchi Metropolis

\begin{tabular}{|c|c|}
\hline $\begin{array}{c}\text { METROPOLIS (2006 } \\
\text { POPULATION) }\end{array}$ & RATIO \\
\hline 493,730 & $\mathbf{8 9 8 : 1}$ \\
\hline
\end{tabular}

From the above table using the 2006 population census, Bauchi metropolis has the ratio of population to police strength 878:1. In essence, it has not met the UN standard ratio of four hundred and fifty people to one police. 


\section{Buffer Zones}

There is no standard distance for citing stations in the country. But a 1 and $2 \mathrm{~km}$ buffers were created on the map to identify area that are fully served or not (see figures 4).

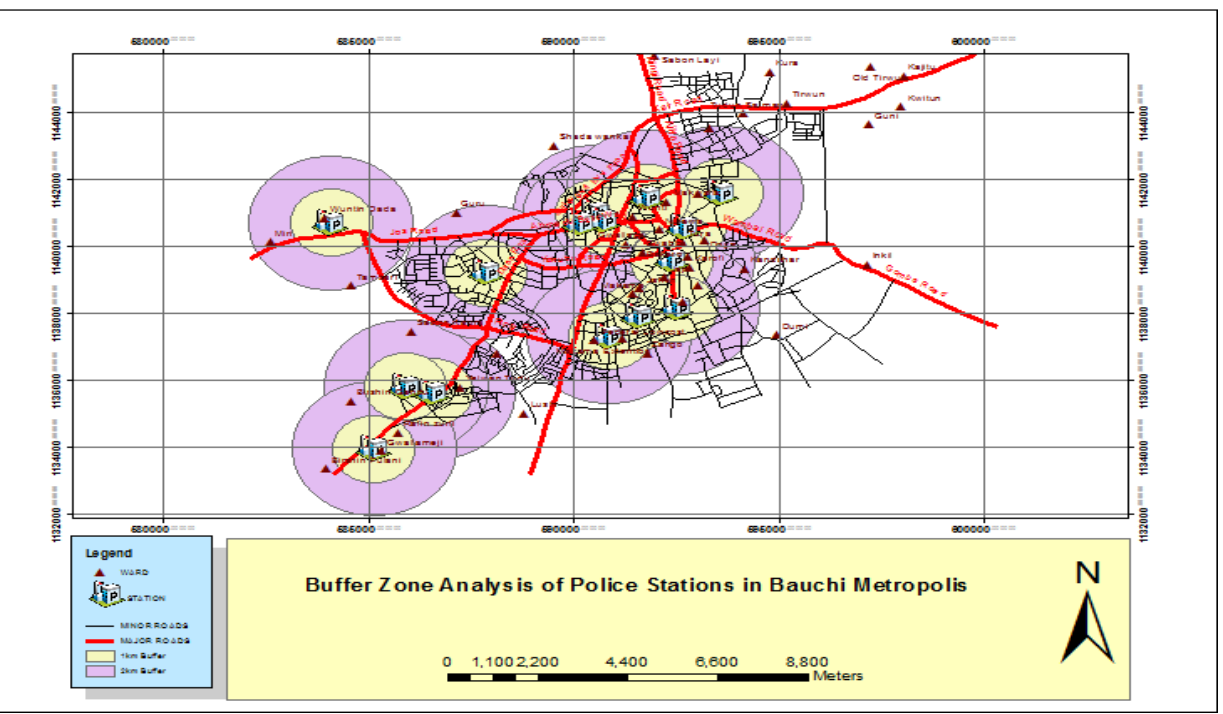

Figure 4: Map Showing 1 km and 2kmBuffer Zone Analysis of Police Stations in Bauchi Metropolis This has shown that the areas inside the city are fully served, considering both 1 and $2 \mathrm{~km}$ buffer. Areas in the east of metropolis are under served and in most of the area people have to travel more than a $\mathrm{km}$ or two to the nearest police station.

tables. The maps can also be thematic in nature. These presentations can be in hardcopy, softcopy and onscreen.

The map generated from the integration of the geographic location of the Police Stations, Results of database queries were presented Schools, Hotel, Markets, Religious Centres and inform of digital maps, graphic displays, or The map below is the digital map produced on animated graphics, photographs, reports, and the course of this project

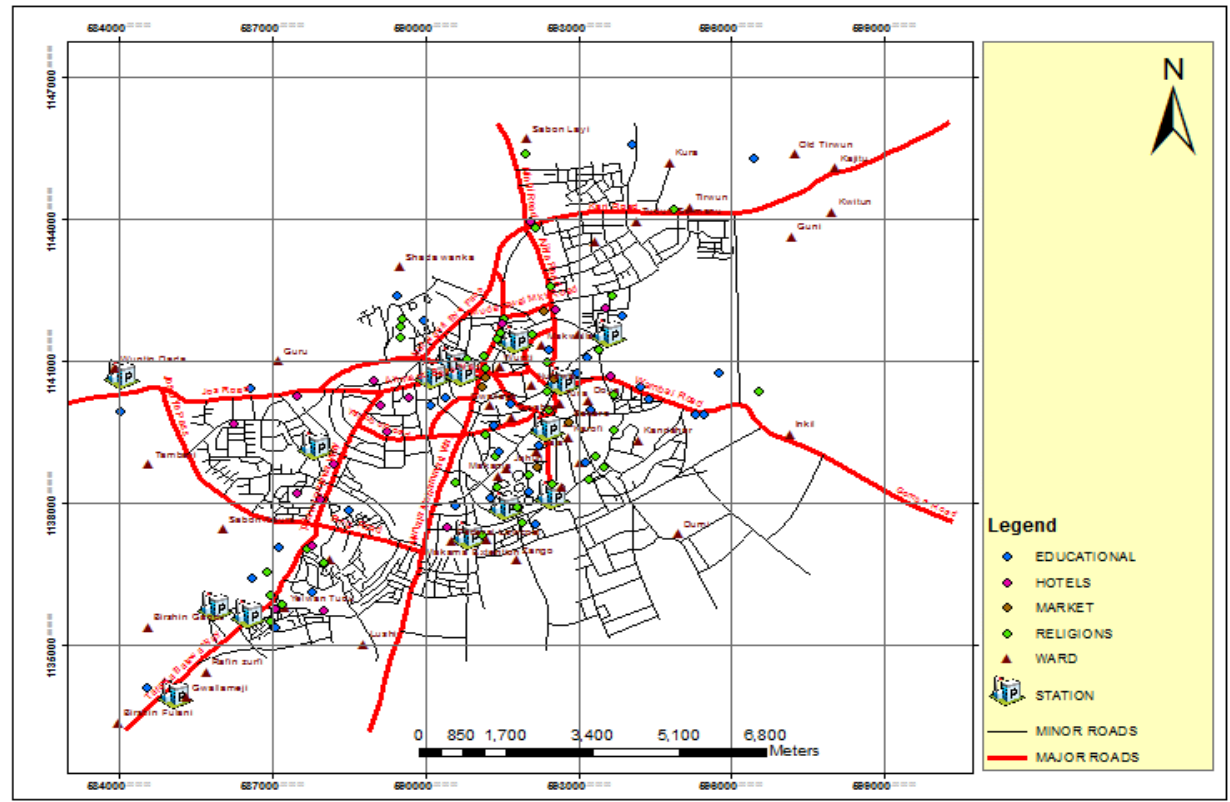

Figure 5: Digital Map of Bauchi Metropolis (study Area) 
Figure 5 shows only the police stations and the wards were superimposed on the Bauchi State street map.

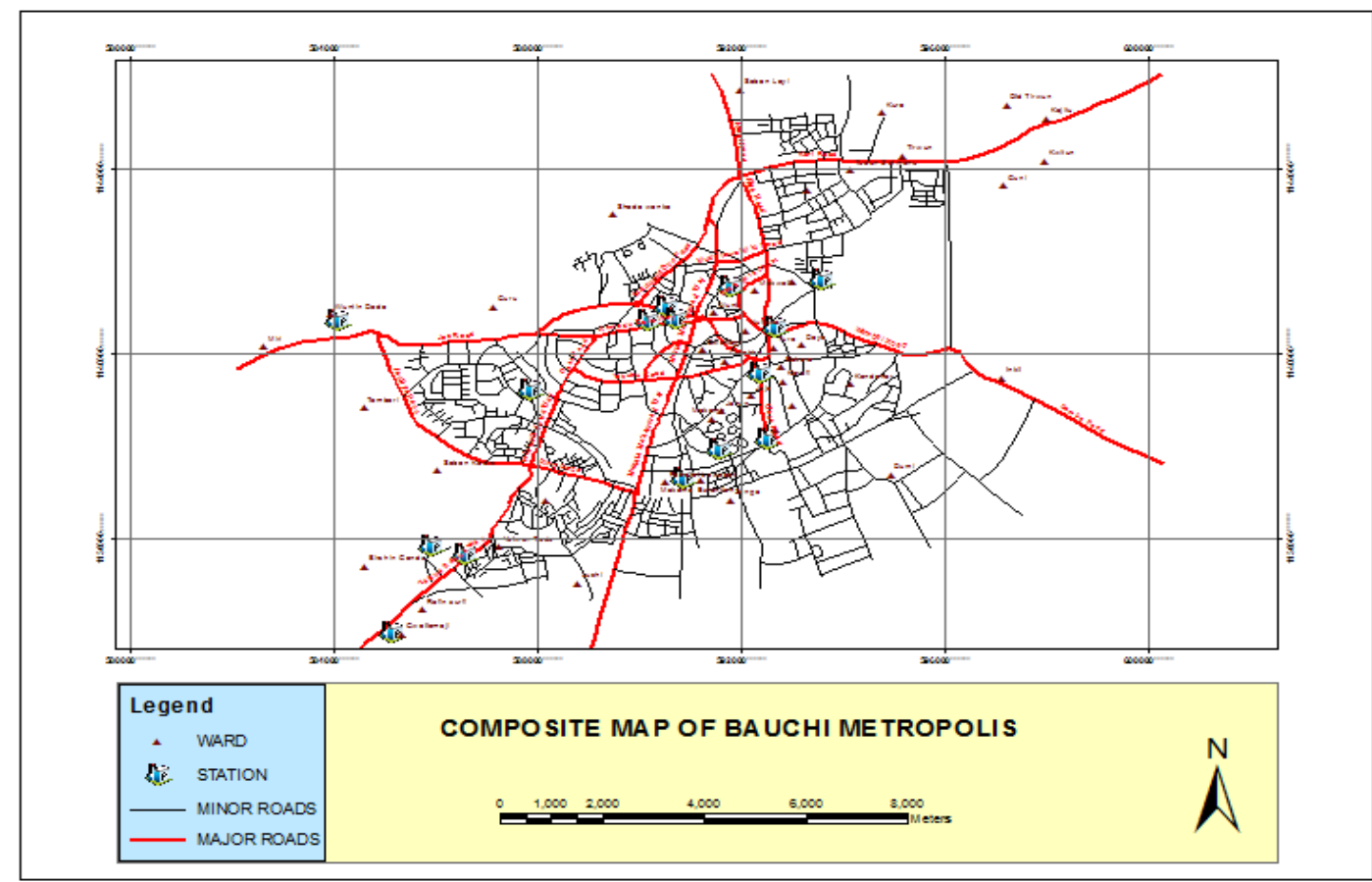

Figure 6: Map Showing the Positions of the Stations (Headquarters, Zone 12 Headquarters, Divisional Police Station Headquarters and Police Outpost).

Figure 7 shows other points of interest which is liable to insecurity.

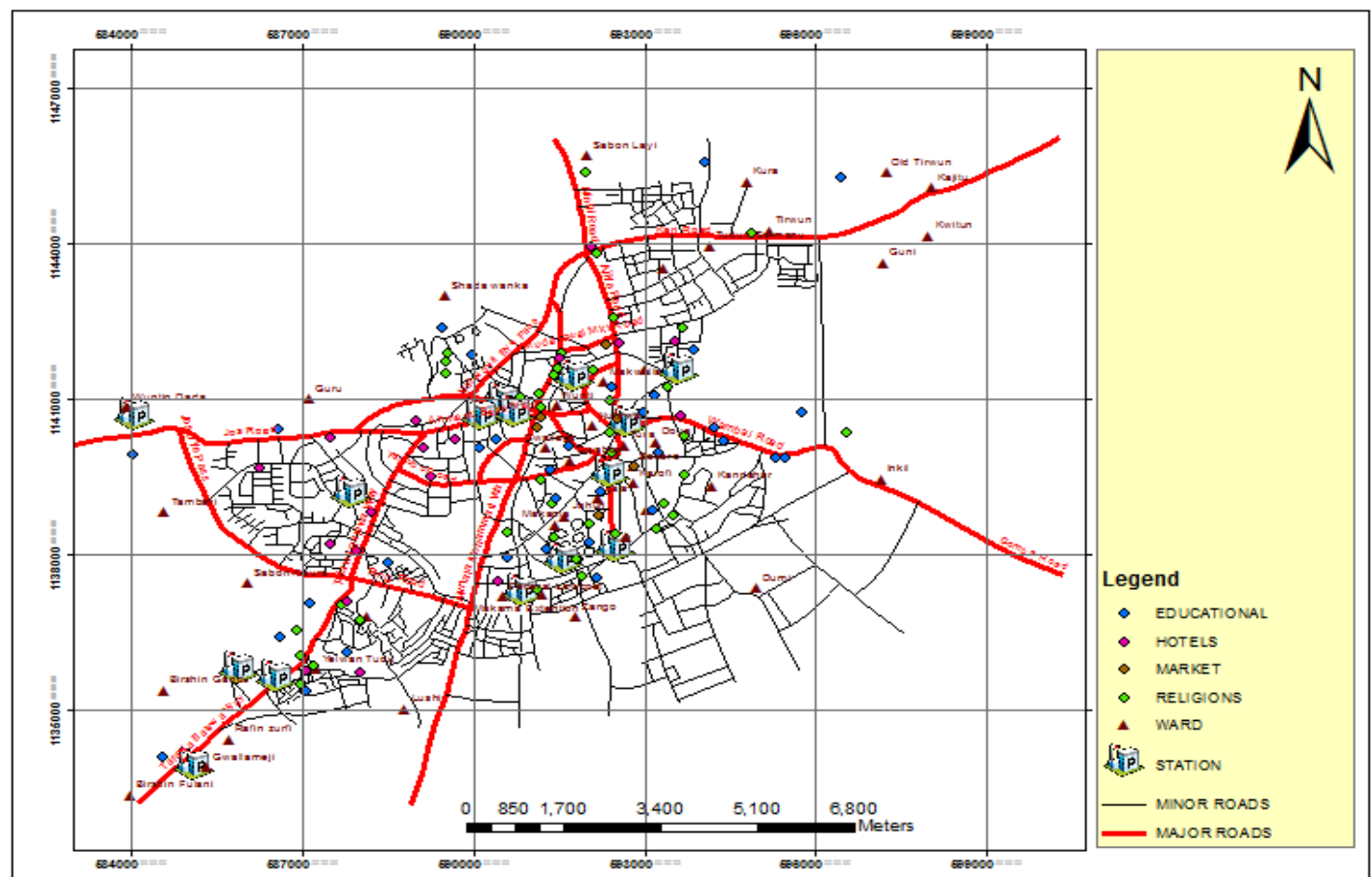

Figure 7: Map Showing Positions of other Points of Interest such as Schools (Educational), Hotels, Markets and Religious Centres. 


\section{IV.CONCLUSION}

Geographic Information System (GIS) technology provides the capability to understand how events relate to each other and their potential impact on infrastructure. The security and safety of citizens create the necessity for GIS to be integrated in an overall Information Technology (IT) infrastructure plan. Security needs is one of the basics for human survival.

It was noticed that the pattern of distribution of police stations in Bauchi metropolis is clustered at the centre of the city, and as one moves away from the centre, the police stations are sparsely distributed. A larger number of police personnel are concentrated in the city of Bauchi metropolis than at the suburbs (districts). This can be attributed to the large population, presence of the police state headquarters and zonal police headquarters located within the Bauchi state capital. From the above study it is very clear that GIS is an effective tool in any discipline with relevance to space, it can be used to identify the location of police stations. This is an attempt to utilize GIS technology and software in policing. Its recommended that population distribution should be a considerable factor in the distribution of police stations and police personnel. There is need for deployment of more police personnel and erection of stations in the metropolis in order to meet the UN recommendation. Therefore Police stations should start using GIS as a tool to plan and improve their services.

\section{REFERENCES}

[1]. M. Ahmed and S. Salihu. "Spatiotemporal Pattern of Crime Using Geographic Information System (GIS) Approach in Dala L.G.A of Kano State, Nigeria. American Journal of Engineering
Research (AJER)e-ISSN: 2320-0847 p-ISSN : 2320-0936 Volume-2, Issue-3, pp-51-58, 2013.

[2]. B. F. Akinbileje, A. A. Ibochi and M. K. Shehu."Geographical information system approach to urban reform: A case study of Makwalla area of Bauchi, Bauchi state, Nigeria.Journal of Environmental Science and Ressources Management, Vol. 4, 2012.

[3]. T. Akuul. "The role of the Nigerian police force in maintaining peace and security in Nigeria," Journal of Social Science and Public Policy. Vol. 3, pp $16-23,2011$.

[4]. C. Anne. "GIS fights crime in Chicago." Article in http://eweek.com enterprise 2004.

[5]. S. E. Arase and I. P. O. Iwouofor. "Policing Nigeria in the 21st century" Spectrum Books Limited, Ibadan, 2007.

[6]. A. B. Dambazau. "The Nigerian police and crime prevention: Criminology and criminal justice," Nigerian Defense Academy Press, Kaduna. Ch 5, pp221, 2007.

[7]. F. Fajemirokun, O. Adewale, T. Idowu, A. A. Oyewusi and B. Maiyegun. "A GIS approach to crime mapping and management in Nigeria: A case study of Victoria Island Lagos." Shaping the Change, XXIII FIG Congress, Munich, Germany, October 8 - 13, 2006.

[8]. V. Henry. "The compstat paradigm: Management accountability in policing, business and the public sector," Looseleaf Law Publications, New York, NY, 2002.

[9]. G. L. Kelling and W. H. Sousa. "Do police matter? An analysis of the impact of New York city's police reforms," Centre for Civic Innovation at the Manhattan institute, New York, NY, 2001.

[10]. A. M. Rikalovic, I. Cosic, R. D. Labati and V. Piuri. "Intelligent decision support system for industrial site classification: A GIS-Based hierarchical neuro-fuzzy approach.” http://www.ieee.org/publications 
standards/publications/rights/index.html for more information. DOI: 10.1109/JSYST.2017.2697043, 2017.

[11]. A. P. Wilson, T. Brown and B. Schuster. "Preventing neighbourhood crime: Geography matters." NIJ Journal, 263: 30 - 35, 2009.

[12]. L. Yin and Z. Cheng. "Study on 3S technology Applied in law enforcement of satellite image" Conference: The 2019 2nd International Conference DOI: 10.1145/3318236.331 8244, 2019.

\section{Cite this article as :}

Ikharo I. Blessing, Ikharo A. Braimoh, "Locational Analysis of Police Stations In Bauchi Metropolis Using GIS Systems", International Journal of Scientific Research in Science and Technology (IJSRST), Online ISSN : 2395-602X, Print ISSN : 2395-6011, Volume 6 Issue 6, pp. 182-190, November-December 2019. Available at doi : https://doi.org/10.32628/IJSRST196636 Journal URL : http://ijsrst.com/IJSRST196636 